\title{
Phenolic Profiles of Hardy Kiwifruits and Their Neuroprotective Effects on PC-12 and SH-SY5Y Cells against Oxidative Stress
}

\author{
Ha-Ram Jeong', Kwan Joong Kim ', Sang Gil Lee ${ }^{2}$, Hye Sung $\mathrm{Cho}^{3}$, Youn-Sup $\mathrm{Cho}^{3}$, and \\ Dae-Ok Kim ${ }^{1,4 *}$ \\ 'Graduate School of Biotechnology, Kyung Hee University, Yongin 17104, Republic of Korea \\ ${ }^{2}$ Department of Food and Nutrition, Pukyoung National University, Busan 48513, Republic of Korea \\ ${ }^{3}$ Jeollanamdo Agricultural Research and Extension Services, Naju 58213, Republic of Korea \\ ${ }^{4}$ Department of Food Science and Biotechnology, Kyung Hee University, Yongin 17104, Republic of Korea
}

Hardy kiwifruits (Actinidia arguta Planch.) have high amounts of antioxidants, including ascorbic acid (vitamin C) and phenolics. The anti-cholinesterase activity and neuroprotective effects of three different cultivars of hardy kiwifruits, cv. Mansu (A. arguta $\times$ A. deliciosa), cv. Haeyeon (A. arguta), and cv. Chiak (A. arguta), on PC-12 and SH-SY5Y cells were evaluated. Extraction of phenolics and vitamin $C$ was carried out using $80 \%(v / v)$ aqueous ethanol and metaphosphoric acid assisted with homogenization, respectively. Hardy kiwifruit of cv. Mansu showed higher total phenolic, total flavonoid, and vitamin C contents and antioxidant capacity compared to the other two cultivars of hardy kiwifruits, cv. Haeyeon and cv. Chiak. Analysis of high-performance liquid chromatography results revealed the presence of procyanidin B2, (-)-epicatechin, neochlorogenic acid, cryptochlorogenic acid, rutin, hyperoside, isoquercitrin, and astragalin in hardy kiwifruits. The three cultivars of hardy kiwifruits had a wide range of vitamin C content of $55.2-130.0 \mathrm{mg} / 100 \mathrm{~g}$ fresh weight. All three cultivars of hardy kiwifruits had protective effects on neuronal PC-12 and SHSY5Y cells exposed to hydrogen peroxide by increasing cell viability and reducing intracellular oxidative stress. Furthermore, the hardy kiwifruits inhibited acetylcholinesterase and butyrylcholinesterase. Collectively, these results suggest that hardy kiwifruits rich in antioxidants like phenolics and vitamin C have good potential as functional materials in neuroprotective applications.

Keywords: Acetylcholinesterase, Actinidia arguta, antioxidant capacity, butyrylcholinesterase, phenolics, vitamin C

Received: January 28, 2020 Accepted: February 17, 2020

First published online: February 18, 2020

* Corresponding author Phone: +82-31-201-3796 Fax: +82-31-204-8116 E-mail:DOKIM05@khu.ac.kr

pISSN 1017-7825 elSSN 1738-8872

Copyright(C) 2020 by The Korean Society for Microbiology and Biotechnology

\section{Introduction}

Hardy kiwifruits (Actinidia arguta) have a smaller non-edible portion than other kiwifruits such as gold kiwifruit (A. chinensis) and green kiwifruit (A. deliciosa) due to their smooth and edible skins. Although hardy kiwifruits are smaller than most common commercial kiwifruits such as A. deliciosa cv. Hayward and A. chinensis cv. Hort 16A [1,2], hardy kiwifruits are gaining popularity in the market. Hardy kiwifruits can withstand cold and frosty environments (up to $-30^{\circ} \mathrm{C}$ ) and are commonly cultivated in mountainous areas with cold climates [3]. Hardy kiwifruits are a good source of vitamin C $[2,4]$ and have a higher total phenolic content than green kiwifruit cv. Hayward [5]. Recently, new cultivars of hardy kiwifruits have been developed and registered in breeding programs in Republic of Korea [6].

Reactive oxygen species (ROS) occur normally or abnormally during oxygen metabolism in the body. ROS are mostly eliminated by antioxidant defense mechanisms including phenolics, vitamin C, and antioxidant enzymes. However, due to imbalance of excessive ROS production, oxidative stress results in neuronal cell damage, causing oxidative modification of proteins, DNA, and lipids, eventually leading to neurological disorders such as Alzheimer's disease [7]. Antioxidants such as phenolics and vitamin $\mathrm{C}$ in foods are known to reduce oxidative stress by scavenging ROS and possibly preventing apoptosis of neuronal cells against oxidative stress $[7,8]$. Protection of neurons in the brain using antioxidants can delay or prevent neurodegeneration caused by excessive and chronic oxidative stress.

Hardy kiwifruits have been reported to show beneficial health effects such as antioxidant, anti-cancer, antihypercholesterolemia, and neuroprotective effects [9-12]. It was previously reported that hardy kiwifruit cultivars showed anti-inflammatory effects, although their phenolic profile was not presented [9]. Various kiwifruits 
including green and hardy kiwifruits have shown neurodegenerative effects partly due to antioxidants such as phenolics and vitamin $C[10,13]$. Cholinesterases including acetylcholinesterase (AChE) and butyrylcholinesterase (BChE) terminate neurotransmission via hydrolysis of the neurotransmitter acetylcholine in neuronal cells. Cholinesterase inhibitors can improve neurotransmission by maintaining normal acetylcholine level in cholinergic synapses. Research regarding cholinesterase inhibitors from natural sources has recently attracted increased attention. Green and gold kiwifruits have been reported to show AChE and BChE inhibitory effects [14]. However, there is limited information of phenolic profiles and neuroprotective effects among cultivars of hardy kiwifruits grown in Republic of Korea.

The present study investigated phenolic profiles and neuroprotective effects of three hardy kiwifruit cultivars, one interspecific hybridization cultivar, A. arguta $\times$ A. deliciosa cv. Mansu, and two other cultivars, A. arguta cv. Haeyeon and cv. Chiak. Total phenolic content, total flavonoid content, vitamin C content, and antioxidant capacity were evaluated in the hardy kiwifruits. To confirm the neuroprotective effects of hardy kiwifruits, cell protective effects on hydrogen peroxide $\left(\mathrm{H}_{2} \mathrm{O}_{2}\right)$-induced PC-12 and SH-SY5Y neuronal cells were examined, and anti-cholinesterase activity against $\mathrm{AChE}$ and $\mathrm{BChE}$ was assessed. Amounts of phenolics and vitamin $\mathrm{C}$ in the hardy kiwifruits were identified and quantified using high-performance liquid chromatography (HPLC).

\section{Materials and Methods \\ Hardy Kiwifruits}

The three hardy kiwifruit cultivars, cv. Mansu (A. arguta $\times$ A. deliciosa), cv. Haeyeon (A. arguta), and cv. Chiak (A. arguta), used in this study were harvested in October 2018 in Jeonnam province, Republic of Korea. As an early maturing cultivar, the hardy kiwifruits were ripened by refrigerated storage at $0^{\circ} \mathrm{C}$ and then kept in a freezer at $-20^{\circ} \mathrm{C}$ prior to use.

\section{Reagents}

Folin-Ciocalteu's phenol reagent, gallic acid, 2,2'-azobis(2-amidinopropane) dihydrochloride (AAPH), 2,2'azino-bis(3-ethylbenzothiazoline-6-sulfonic acid) diammonium salt (ABTS), $L$-ascorbic acid (vitamin C), 1,1diphenyl-1-picrylhydrazyl (DPPH), 2,4,6-tris(2-pyridyl)-s-triazine (TPTZ), ferric chloride $\left(\mathrm{FeCl}_{3}\right)$, sodium acetate, (+)-catechin, (-)-epicatechin, neochlorogenic acid, cryptochlorogenic acid, rutin, isoquercitrin, hyperoside, dimethyl sulfoxide (DMSO), 2',7'-dichlorofluorescin diacetate (DCFH-DA), 3-(4,5-dimethylthiazol2-yl)-2,5-diphenyltetrazolium bromide (MTT), $30 \% \mathrm{H}_{2} \mathrm{O}_{2}$, aluminium chloride $\left(\mathrm{AlCl}_{3}\right.$ ), phosphate buffered saline (PBS), sodium nitrite $\left(\mathrm{NaNO}_{2}\right)$, tacrine, AChE, acetylthiocholine iodide (ATCI), BChE, butyrylthiocholine iodide (BTCI), 5,5'-dithiobis-(2-nitrobenzoic acid) (DTNB), metaphosphoric acid, and formic acid were purchased from Sigma Aldrich Co., LLC (USA). Procyanidin B2 and astragalin were purchased from Extrasynthese (Genay, France). Methanol, ethanol, and sodium hydroxide $(\mathrm{NaOH})$ were purchased from Daejung Chemicals \& Metals Co., Ltd. (Republic of Korea). Sodium carbonate $\left(\mathrm{Na}_{2} \mathrm{CO}_{3}\right)$ was purchased from Yakuri Pure Chemicals Co., Ltd. (Japan). Dulbecco's phosphate buffered saline (DPBS), penicillin/streptomycin, fetal bovine serum (FBS), Hank's balanced salt solution (HBSS), minimum essential medium (MEM), and Roswell Park Memorial Institute (RPMI)-1640 medium were purchased from Welgene Inc. (Republic of Korea). All reagents used were of analytical or HPLC grade.

\section{Extraction of Phenolics and Vitamin C}

Extraction was carried out using a homogenizer (PT 2500 E; Kinematica AG, Switzerland). Fifty grams of hardy kiwifruit was immersed in $100 \mathrm{ml}$ of $80 \%(\mathrm{v} / \mathrm{v})$ aqueous ethanol and homogenized at 15,000 rpm for $2 \mathrm{~min}$. The homogenized hardy kiwifruits in solvent were separated using a centrifugal separator (VS-6000CFi; Vision Science Co., Ltd., Republic of Korea) at 2,200 $\times g$ for $10 \mathrm{~min}$. The extract was filtered using filter paper (Whatman Grade 2; Whatman plc, UK), and the residue (filter cake) was re-extracted by repeating the above procedure. The two filtrates were combined and evaporated using a rotary evaporator equipped with a vacuum pump and cooling controller (Eyela, Japan) at $40^{\circ} \mathrm{C}$. Extracts of hardy kiwifruits were independently obtained three replicates and stored at $-20^{\circ} \mathrm{C}$ prior to use.

Vitamin C extraction from hardy kiwifruits was carried out according to the modified method of Lee et al. [15]. In brief, $2 \mathrm{~g}$ of hardy kiwifruits was immersed in $5 \mathrm{ml}$ of $10 \%(\mathrm{w} / \mathrm{v})$ metaphosphoric acid solution for 10 min. Fifteen milliliters of $5 \%(\mathrm{w} / \mathrm{v})$ metaphosphoric acid solution was added to the mixture, followed by homogenization at 15,000 rpm for 2 min using a homogenizer (PT 2500 E; Kinematica AG). The homogenized mixture was separated using a centrifugal separator (VS-6000CFi; Vision Science Co., Ltd.). The final volume for vitamin $\mathrm{C}$ analysis was adjusted to $50 \mathrm{ml}$ with $5 \%(\mathrm{w} / \mathrm{v})$ metaphosphoric acid solution. Three independent extractions of vitamin $\mathrm{C}$ in hardy kiwifruit were carried out.

\section{Measurement of Total Phenolic Content}

Total phenolic content was measured using Folin-Ciocalteu's phenol reagent [16]. Two hundred microliters of each hardy kiwifruit extract was diluted in $2.6 \mathrm{ml}$ of deionized water. Two hundred microliters of Folin-Ciocalteu's phenol reagent was mixed with the diluted sample and reacted at $23^{\circ} \mathrm{C}$ for $6 \mathrm{~min}$. The mixture was then added to $2 \mathrm{ml}$ of $7 \%(\mathrm{w} / \mathrm{v}) \mathrm{Na}_{2} \mathrm{CO}_{3}$ solution and allowed to stand for $84 \mathrm{~min}$. The absorbance of the reacted mixture was determined at $750 \mathrm{~nm}$ using a spectrophotometer (SPECTRONIC 200; Thermo Fisher Scientific Inc., USA). Total phenolic content was expressed as mg gallic acid equivalents (GAE)/100 $\mathrm{g}$ fresh weight (FW). 


\section{Measurement of Total Flavonoid Content}

Total flavonoid content was measured using a colorimetric method [17]. In brief, $0.5 \mathrm{ml}$ of each hardy kiwifruit extract was mixed with $3.2 \mathrm{ml}$ of deionized water. One hundred fifty microliters of $5 \%(\mathrm{w} / \mathrm{v}) \mathrm{NaNO}_{2}$ solution was added, and the solution was held for $5 \mathrm{~min}$. Then, $150 \mu \mathrm{l}$ of $10 \%(\mathrm{w} / \mathrm{v}) \mathrm{AlCl}_{3}$ solution was added and reacted for $1 \mathrm{~min}$. Next, $1 \mathrm{ml}$ of $1 \mathrm{M} \mathrm{NaOH}$ solution was added, and the absorbance of the mixture was immediately measured at $510 \mathrm{~nm}$ using a spectrophotometer (SPECTRONIC 200). Total flavonoid content was expressed as mg catechin equivalents (CE)/100 g FW.

\section{Measurement of Antioxidant Capacity}

In the ABTS assay [16], PBS solution ( $\mathrm{pH}$ 7.4) containing AAPH and ABTS was heated in a water bath at $70^{\circ} \mathrm{C}$ for $30 \mathrm{~min}$ to prepare the ABTS radical solution. The absorbance of the ABTS radical solution was adjusted to $0.650 \pm 0.020$ with PBS at $734 \mathrm{~nm}$ using a spectrophotometer (SPECTRONIC 200). Hardy kiwifruit extract (20 $\mu \mathrm{l}$ ) and ABTS radical solution $(980 \mu \mathrm{l})$ were mixed and allowed to react in a water bath at $37^{\circ} \mathrm{C}$ for $10 \mathrm{~min}$. The reduction in absorbance of the mixture was measured at $734 \mathrm{~nm}$ using a spectrophotometer (SPECTRONIC 200). The antioxidant capacity of the kiwifruits was expressed as mg vitamin C equivalents (VCE)/100 g FW.

In the DPPH assay [16], DPPH radical solution was prepared by dissolving $0.1 \mathrm{mM} \mathrm{DPPH}$ in $200 \mathrm{ml}$ of $80 \%$ (v/v) aqueous methanol followed by adjustment of the absorbance with $80 \%(\mathrm{v} / \mathrm{v})$ aqueous methanol to $0.650 \pm 0.020$ at $517 \mathrm{~nm}$ using a spectrophotometer (SPECTRONIC 200). Fifty microliters of each diluted hardy kiwifruit extract and $2.95 \mathrm{ml}$ of DPPH radical solution were mixed and reacted at room temperature for $30 \mathrm{~min}$. The reduction in absorbance of the mixture was measured at $517 \mathrm{~nm}$ using a spectrophotometer (SPECTRONIC 200). The antioxidant capacity was expressed as $\mathrm{mg}$ VCE/100 g FW.

The ferric reducing antioxidant power (FRAP) assay was carried out using the modified method of Benzie and Strain [18]. The FRAP reagent was prepared by mixing $10 \mathrm{mM}$ TPTZ with $40 \mathrm{mM} \mathrm{HCl}$ solution, $20 \mathrm{mM} \mathrm{FeCl}_{3}$ solution, and $0.3 \mathrm{M}$ sodium acetate buffer $(\mathrm{pH} 3.6)$ at a ratio of 1:1:10. Fifty microliters of hardy kiwifruit extract and $0.95 \mathrm{ml}$ of FRAP reagent were mixed and reacted at $23^{\circ} \mathrm{C}$ for $30 \mathrm{~min}$. The absorbance of the mixture was measured at $593 \mathrm{~nm}$ using a spectrophotometer (SPECTRONIC 200). The antioxidant capacity was expressed as $\mathrm{mg} \mathrm{VCE} / 100 \mathrm{~g}$ FW.

\section{Quantification of Phenolics and Vitamin C Using HPLC}

Individual phenolics in hardy kiwifruits were quantitatively analyzed using a reversed-phase HPLC system (Agilent 1200; Agilent Technologies, USA) equipped with a diode array detector, degasser, and autosampler. A reversed-phase analytical C18 column (Agilent Zorbax Eclipse XDB-C18, $250 \times 4.6 \mathrm{~mm}, 5 \mu \mathrm{m}$ ) was used at $20^{\circ} \mathrm{C}$. The injection volume was $10 \mu \mathrm{l}$, and the flow rate was $0.8 \mathrm{ml} / \mathrm{min}$. The gradient for the two mobile phases (solvent A, water with $0.1 \%(\mathrm{v} / \mathrm{v})$ formic acid; solvent $\mathrm{B}$, acetonitrile with $0.1 \%(\mathrm{v} / \mathrm{v})$ formic acid) was as follows: $95 \% \mathrm{~A} / 5 \%$ $\mathrm{B}$ at $0 \mathrm{~min}, 85 \% \mathrm{~A} / 15 \% \mathrm{~B}$ at $25 \mathrm{~min}, 65 \% \mathrm{~A} / 35 \% \mathrm{~B}$ at $45 \mathrm{~min}, 30 \% \mathrm{~A} / 70 \% \mathrm{~B}$ at $50 \mathrm{~min}, 20 \% \mathrm{~A} / 80 \% \mathrm{~B}$ at $58 \mathrm{~min}, 95 \%$ $\mathrm{A} / 5 \% \mathrm{~B}$ at $60 \mathrm{~min}$, and $95 \% \mathrm{~A} / 5 \% \mathrm{~B}$ at $65 \mathrm{~min}$. To detect the individual phenolics, the wavelength was set at $280 \mathrm{~nm}$ for procyanidin $\mathrm{B} 2$ and (-)-epicatechin, at $320 \mathrm{~nm}$ for neochlorogenic and cryptochlorogenic acids, and at $370 \mathrm{~nm}$ for rutin, hyperoside, isoquercitrin, and astragalin. Individual phenolics in the three cultivars of hardy kiwifruit were quantified using standard curves of commercial standards of procyanidin B2, (-)-epicatechin, neochlorogenic acid, cryptochlorogenic acid, rutin, hyperoside, isoquercitrin, and astragalin.

Vitamin C content in the hardy kiwifruits was analyzed using a reversed-phase HPLC system (Agilent 1200; Agilent Technologies) equipped with a diode array detector, degasser, and autosampler. A reversed-phase analytical C18 column (Agilent Zorbax Eclipse XDB-C18, $250 \times 4.6 \mathrm{~mm}, 5 \mu \mathrm{m}$ ) was used at $30^{\circ} \mathrm{C}$. Injection volume was $10 \mu \mathrm{l}$, and the flow rate was $0.8 \mathrm{ml} / \mathrm{min}$. The gradient for the two mobile phases (solvent $\mathrm{A}$, water with $0.1 \%(\mathrm{v} / \mathrm{v})$ formic acid; solvent $\mathrm{B}$, acetonitrile with $0.1 \%(\mathrm{v} / \mathrm{v})$ formic acid) was as follows: $100 \% \mathrm{~A} / 0 \% \mathrm{~B}$ at $0 \mathrm{~min}$, $97 \% \mathrm{~A} / 3 \% \mathrm{~B}$ at $8 \mathrm{~min}, 50 \% \mathrm{~A} / 50 \% \mathrm{~B}$ at $10 \mathrm{~min}, 20 \% \mathrm{~A} / 80 \% \mathrm{~B}$ at $12 \mathrm{~min}, 100 \% \mathrm{~A} / 0 \% \mathrm{~B}$ at $15 \mathrm{~min}$, and $100 \% \mathrm{~A} / 0 \% \mathrm{~B}$ at $20 \mathrm{~min}$. The wavelength of the detector was set at $254 \mathrm{~nm}$. Vitamin $\mathrm{C}$ in the three cultivars of hardy kiwifruits was quantified using the vitamin $\mathrm{C}$ standard curve.

\section{Cell Culture}

The PC-12 cell line, derived from a rat pheochromocytoma, was obtained from the American Type Culture Collection (USA). The SH-SY5Y cell line, derived from a human neuroblastoma, was obtained from the Korean Cell Line Bank (Republic of Korea). The PC-12 cell line was cultured in RPMI 1640 medium containing 10\% FBS, 100 units $/ \mathrm{ml}$ penicillin, and $100 \mu \mathrm{g} / \mathrm{ml}$ streptomycin, and the SH-SY5Y cells were cultured in MEM medium containing $10 \% \mathrm{FBS}, 100 \mathrm{units} / \mathrm{ml}$ penicillin, and $100 \mu \mathrm{g} / \mathrm{ml}$ streptomycin. Two neuronal cell lines (PC-12 and SH-SY5Y) were incubated in a humidified incubator $\left(\mathrm{CO}_{2}\right.$ incubator BB 15; Thermo Electron LED GmbH, Germany) with $5 \% \mathrm{CO}_{2}$ at $37^{\circ} \mathrm{C}$.

\section{Measurement of Cell Viability}

The cytotoxicity and cell viability of hardy kiwifruit extracts were measured as described by Heo et al. [19] with some modifications. The PC-12 cells were pre-cultured in a 96-well plate at a density of $2 \times 10^{4}$ cells $/$ well for $24 \mathrm{~h}$, and SH-SY5Y cells were pre-cultured in a 96-well plate at a density of $1 \times 10^{5}$ cells/well for $24 \mathrm{~h}$. After removal of the supernatant, PC-12 and SH-SY5Y cells were treated for $24 \mathrm{~h}$ with serum-free medium containing various concentrations of hardy kiwifruit extracts. The PC-12 cells were treated with $100 \mu \mathrm{L}$ of $200 \mu \mathrm{M} \mathrm{H}_{2} \mathrm{O}_{2}$ for $1 \mathrm{~h}$, whereas the SH-SY5Y cells were treated with $100 \mu \mathrm{l}$ of $100 \mu \mathrm{M} \mathrm{H}_{2} \mathrm{O}_{2}$ for $1 \mathrm{~h}$. PC-12 and SH-SY5Y cells were treated with $100 \mu \mathrm{l}$ of $0.83 \mathrm{mM}$ MTT solution for $3 \mathrm{~h}$. The formazan produced in the PC-12 and SH-SY5Y cells was 
dissolved in $50 \mu \mathrm{l}$ of DMSO. The absorbance of formazan was measured at $570 \mathrm{~nm}$ using a microplate reader (Infinite M200; Tecan Austria GmbH, Austria). The cytotoxicity and viability of the PC-12 and SH-SY5Y cells were expressed as percentage (\%) of viable cells relative to control cells (100\%) that were not treated with $\mathrm{H}_{2} \mathrm{O}_{2}$ or hardy kiwifruit extract.

\section{Measurement of Intracellular Oxidative Stress}

Intracellular oxidative stress levels were determined by a fluorescent assay using DCFH-DA [20]. PC-12 cells (density of $2 \times 10^{4}$ cells/well) and SH-SY5Y cells (density of $1 \times 10^{5}$ cells/well) were pre-cultured in 96-well plates for $24 \mathrm{~h}$. After removal of the supernatant, PC-12 and SH-SY5Y cells were treated with serum-free medium containing various concentrations of hardy kiwifruit extracts. PC-12 and SH-SY5Y cells were treated with $100 \mu \mathrm{l}$ of $50 \mu \mathrm{M}$ DCFH-DA in HBSS for $1 \mathrm{~h}$ and exposed to oxidative stress using $100 \mu \mathrm{l}$ of $200 \mu \mathrm{M}$ and $100 \mu \mathrm{M} \mathrm{H}_{2} \mathrm{O}_{2}$ for $1 \mathrm{~h}$, respectively. Fluorescence was measured using a microplate reader (Infinite M200; Tecan Austria GmbH) with excitation and emission wavelengths of $485 \mathrm{~nm}$ and $535 \mathrm{~nm}$, respectively. The intracellular oxidative stress levels were expressed as percentage (\%) of viable cells relative to control cells (100\%) that were not treated with $\mathrm{H}_{2} \mathrm{O}_{2}$ or hardy kiwifruit extract.

\section{Measurement of Anti-Cholinesterase Activity}

The anti-cholinesterase activity was assessed using two enzymes (AChE and BChE) in 96-well plates by a modified DTNB assay method [21]. In the AChE inhibition assay, $150 \mu$ lof potassium phosphate buffer ( $\mathrm{pH} 7.4$ ) was dispensed into 96-well plates. Twenty microliters of hardy kiwifruit extracts, $20 \mu \mathrm{l}$ of the ATCI substrate $(15 \mathrm{mM})$, and $30 \mu \mathrm{l}$ of DTNB indicator $(10 \mathrm{mM})$ were sequentially added and reacted at $37^{\circ} \mathrm{C}$ for $10 \mathrm{~min}$. Twenty microliters of AChE $(0.2 \mathrm{U})$ was added to the mixture followed by incubation at $37^{\circ} \mathrm{C}$ for $30 \mathrm{~min}$. The absorbance was measured at $415 \mathrm{~nm}$ using a microplate reader (Infinite M200; Tecan Austria GmbH). In the BChE inhibition assay, $20 \mu \mathrm{l}$ of BTCI substrate $(10 \mathrm{mM})$ and $20 \mu \mathrm{l}$ of BChE $(0.06 \mathrm{U})$ were added instead of the ATCI substrate and $\mathrm{AChE}$ in the AChE inhibition assay. Instead of $20 \mu \mathrm{l}$ of kiwifruit extract, the same amount of potassium phosphate buffer was used in the control. AChE and BChE inhibitions were calculated using the following formula: cholinesterase inhibition $(\%)=1-($ sample absorbance/control absorbance $) \times 100$.

\section{Statistical Analysis}

Data of three replicate determinations are presented as the mean \pm standard deviation. Statistical analyses were carried out using IBM SPSS software Version 23 (IBM SPSS Statistics Inc., USA). All tests were evaluated for significance of differences in average values using Duncan's multiple range test $(p<0.05)$.

\section{Results and Discussion}

\section{Total Phenolic and Flavonoid Contents}

Total phenolic and flavonoid contents of three cultivars of hardy kiwifruits (cv. Mansu, cv. Haeyeon, and cv. Chiak) are shown in Table 1 and decreased as follows: cv. Mansu >cv. Chiak >cv. Haeyeon. The variations in total phenolic and flavonoid contents of kiwifruits in this study can be ascribed to the differences in cultivars. Similar to the results of total phenolic content in this study, it was previously reported that $\mathrm{cv}$. Mansu showed a higher total phenolic content than cv. Haeyeon and cv. Chiak [9]. Cv. Chiak, however, unlike the results of total phenolic content in this study, was reported to have the highest total flavonoid content among the three kiwifruit cultivars [9]. It is possible that the different rankings of total flavonoid content are partly due to differences in date of harvest.

It was previously reported that hardy kiwifruits have higher total phenolic content than green kiwifruit cv. Hayward but lower content than gold kiwifruit cv. Hort16A [1]. Similar to our total phenolic content results, a wide range of total phenolic content of various cultivars of hardy kiwifruits of 79.2-341.4 mg GAE/100 g FW was reported [22]. Total phenolic content of hardy kiwifruits has been reported to be higher than that of other fruits such as apples, lemons, bananas, and oranges [23]. Total phenolic and flavonoid content results of this study confirm that hardy kiwifruits are a good source of phenolics, including flavonoids.

Table 1. Total phenolic and flavonoid contents and antioxidant capacities of three cultivars of hardy kiwifruits.

\begin{tabular}{lccccc}
\hline Cultivar & $\begin{array}{c}\text { Total phenolic content } \\
\left(\mathrm{mg} \mathrm{GAE}^{1} / 100 \mathrm{~g} \mathrm{FW}^{2}\right)\end{array}$ & $\begin{array}{c}\text { Total flavonoid content } \\
\left(\mathrm{mg} \mathrm{CE}^{3} / 100 \mathrm{~g} \mathrm{FW}\right)\end{array}$ & & \multicolumn{3}{c}{$\begin{array}{c}\text { Antioxidant capacity } \\
\left(\mathrm{mg} \mathrm{VCE} / 100 \mathrm{~g} \mathrm{FW}^{4}\right)\end{array}$} \\
\cline { 3 - 6 } & $277.2 \pm 4.6^{\mathrm{a} 8}$ & $62.5 \pm 5.1^{\mathrm{a}}$ & $319.2 \pm 4.6^{\mathrm{a}}$ & $289.2 \pm 7.3^{\mathrm{a}}$ & $234.6 \pm 6.2^{\mathrm{a}}$ \\
\cline { 3 - 7 } & $162.0 \pm 4.8^{\mathrm{c}}$ & $41.4 \pm 2.3^{\mathrm{b}}$ & $170.7 \pm 4.6^{\mathrm{c}}$ & $136.1 \pm 2.7^{\mathrm{c}}$ & $117.6 \pm 3.3^{\mathrm{c}}$ \\
Haeyeon & $178.6 \pm 4.3^{\mathrm{b}}$ & $42.6 \pm 3.5^{\mathrm{b}}$ & $192.1 \pm 5.3^{\mathrm{b}}$ & $151.5 \pm 4.9^{\mathrm{b}}$ & $134.8 \pm 1.2^{\mathrm{b}}$ \\
\hline
\end{tabular}

${ }^{1-4}$ GAE, FW, CE, and VCE stand for gallic acid equivalents, fresh weight, catechin equivalents, and vitamin $\mathrm{C}$ equivalents, respectively.

${ }^{5} 2,2$-Azino-bis(3-ethylbenzothiazoline-6-sulphonic acid) radical scavenging assay

${ }^{6}$ 2,2-Diphenyl-1-picrylhydrazyl radical scavenging assay

${ }^{7}$ Ferric reducing antioxidant power assay

${ }^{8}$ Data are expressed as mean \pm standard deviation $(n=3)$. Means with different superscripts in the same column indicate significant difference based on Duncan's multiple range test $(p<0.05)$. 


\section{Antioxidant Capacity}

Like vitamin $\mathrm{C}$ that acts as an antioxidant, phenolics, a group of plant secondary metabolites, have antioxidant effects by scavenging free radicals due to their free hydroxyl $(-\mathrm{OH})$ group on the aromatic ring [24]. The antioxidant capacity of three cultivars of kiwifruits measured using three assays (ABTS, DPPH, and FRAP assays) are shown in Table 1. Like the trends of total phenolic and flavonoid contents, the antioxidant capacity of the three cultivars of kiwifruits decreased as follows: cv. Mansu > cv. Chiak > cv. Haeyeon.

It was previously reported that the antioxidant capacity of hardy kiwifruit cultivars decreased as follows: $\mathrm{cv}$. Mansu > cv. Chiak > cv. Haeyeon [9]. Hardy kiwifruits were previously reported to show higher antioxidant capacity than green kiwifruit cv. Hayward but lower than gold kiwifruit cv. Hort16A [1]. Hardy kiwifruits have been reported to have antioxidant capacities in wide ranges of 97-422 mg VCE/100 g FW and 101-266 mg VCE/ $100 \mathrm{~g} \mathrm{FW}$ based on ABTS and DPPH assays [22], respectively, which is similar to the antioxidant capacity results of this study.

Quantification of Phenolics and Vitamin C using Reversed-Phase HPLC

As shown in Table 2, two phenolic acids (cryptochlorogenic acid (4-O-caffeoylquinic acid) and neochlorogenic acid (3-O-caffeoylquinic acid)), one flavan-3-ol ((-)-epicatechin), four flavonols (astragalin (kaempferol-3-Oglucoside), hyperoside (quercetin-3-O-galactoside), isoquercitrin (quercetin-3-O-glucoside), and rutin (quercetin3 -O-rutinoside)), and one condensed tannin (procyanidin B2 $((-)$-epicatechin- $(4 \beta \rightarrow 8)$-(-)-epicatechin)) were identified in the three hardy kiwifruit cultivars (Table 2). The phenolics identified in this study were previously reported in many cultivars of hardy kiwifruits $[4,10,25]$. The amounts of the eight phenolics in the three cultivars of hardy kiwifruits are presented in Table 2. The sum of concentrations of the eight phenolics identified in the three cultivars of hardy kiwifruit decreased as follows: cv. Chiak $(10.1 \mathrm{mg} / 100 \mathrm{~g} \mathrm{FW})>\mathrm{cv}$. Mansu $(9.3 \mathrm{mg} / 100 \mathrm{~g}$ $\mathrm{FW})>\mathrm{cv}$. Haeyeon $(6.3 \mathrm{mg} / 100 \mathrm{~g} \mathrm{FW})$.

Vitamin C (ascorbic acid) content of the three hardy kiwifruits investigated in this study was in the range of $55.2-130.0 \mathrm{mg} / 100 \mathrm{~g} \mathrm{FW}$ (Table 2). The hardy kiwifruits evaluated in this study were revealed to be a rich source of vitamin C. Similar to the vitamin $\mathrm{C}$ results of this study, hardy kiwifruits have been reported to have vitamin $\mathrm{C}$ content of 37.3-282.6 mg/100 g FW [1, 2, 4, 22]. The phenolic and vitamin C contents vary according to cultivar and harvest season $[4,22]$. In this study, the amounts of phenolics and vitamin $\mathrm{C}$ were dependent on hardy kiwifruit cultivar (Table 2).

\section{Neuronal Cell Protective Effects of Hardy Kiwifruits}

The cytotoxicity of hardy kiwifruits was examined to determine the maximal non-toxic concentrations. Cell viabilities less than $90 \%$ of PC- 12 cells and less than $80 \%$ of SH-SY5Y cells were considered toxic after pretreatment of hardy kiwifruit extracts without oxidative stress. The three cultivars of hardy kiwifruit extracts were non-toxic up to $400 \mu \mathrm{g} / \mathrm{ml}$ on PC-12 cells and $50 \mu \mathrm{g} / \mathrm{ml}$ on SH-SY5Y cells (data not shown).

Under oxidative stress induced with $200 \mu \mathrm{M} \mathrm{H}_{2} \mathrm{O}_{2}$, the viability of PC-12 cells was reduced to approximately $73.0 \%$, which is lower than that of the control (100\%) (Fig. 1A). Pretreatment of PC-12 cells with extracts of cv. Mansu, cv. Haeyeon, and cv. Chiak at concentration of $400 \mu \mathrm{g} / \mathrm{ml}$ resulted in cell viabilities of approximately $87.1 \%, 91.3 \%$, and $85.4 \%$, respectively, which are significantly $(p<0.05)$ greater than that of the negative control (73.0\%) treated with only $\mathrm{H}_{2} \mathrm{O}_{2}$ (Fig. 1A).

Under oxidative stress induced with $100 \mathrm{\mu M} \mathrm{H}_{2} \mathrm{O}_{2}$, viability of SH-SY5Y cells decreased to approximately $67.2 \%$ (Fig. 1B). Pretreatment of SH-SY5Y cells with extracts of cv. Mansu, cv. Haeyeon, and cv. Chiak at concentration of $50 \mu \mathrm{g} / \mathrm{ml}$ showed cell viabilities of approximately $85.7 \%, 86.3 \%$, and $72.5 \%$, respectively, which are greater than that of the negative control (67.2\%) (Fig. 1B). In this study, hardy kiwifruits increased the cell viability of two neuronal lines, PC-12 and SH-SY5Y, partly due to the prevention of mitochondial dysfunction from oxidative stress.

Table 2. Quantification of phenolics and vitamin $\mathrm{C}$ in the three cultivars of hardy kiwifruit using reversedphase HPLC.

\begin{tabular}{|c|c|c|c|}
\hline \multirow{2}{*}{ Phytochemical } & \multicolumn{3}{|c|}{ Concentration (mg/100 g fresh weight) } \\
\hline & cv. Mansu & cv. Haeyeon & cv. Chiak \\
\hline Vitamin C & $130.0 \pm 14.4^{\mathrm{a} 1}$ & $55.2 \pm 5.6^{\mathrm{b}}$ & $76.1 \pm 12.0^{\mathrm{b}}$ \\
\hline Procyanidin B2 & $2.18 \pm 0.07^{\mathrm{b}}$ & $3.14 \pm 0.10^{\mathrm{a}}$ & $1.96 \pm 0.19^{\mathrm{b}}$ \\
\hline (-)-Epicatechin & $1.10 \pm 0.03^{\mathrm{a}}$ & $1.03 \pm 0.03^{\mathrm{b}}$ & $1.00 \pm 0.04^{\mathrm{b}}$ \\
\hline Neochlorogenic acid & $2.34 \pm 0.01^{\mathrm{b}}$ & $1.20 \pm 0.02^{\mathrm{c}}$ & $3.96 \pm 0.13^{\mathrm{a}}$ \\
\hline Cryptochlorogenic acid & $0.08 \pm 0.00^{\mathrm{b}}$ & $0.03 \pm 0.00^{c}$ & $0.18 \pm 0.01^{\mathrm{a}}$ \\
\hline Rutin & $0.57 \pm 0.02^{\mathrm{b}}$ & $0.13 \pm 0.00^{\mathrm{c}}$ & $0.86 \pm 0.02^{\mathrm{a}}$ \\
\hline Hyperoside & $0.66 \pm 0.02^{\mathrm{a}}$ & $0.17 \pm 0.01^{c}$ & $0.48 \pm 0.03^{\mathrm{b}}$ \\
\hline Isoquercitrin & $1.84 \pm 0.07^{\mathrm{a}}$ & $0.42 \pm 0.03^{\mathrm{c}}$ & $1.23 \pm 0.07^{b}$ \\
\hline Astragalin & $0.50 \pm 0.02^{\mathrm{a}}$ & $0.19 \pm 0.01^{c}$ & $0.39 \pm 0.02^{\mathrm{b}}$ \\
\hline Sum of phenolics & $9.3 \pm 0.9^{\mathrm{a}}$ & $6.3 \pm 1.0^{\mathrm{b}}$ & $10.1 \pm 1.2^{\mathrm{a}}$ \\
\hline
\end{tabular}

${ }^{1}$ Data are expressed as mean \pm standard deviation $(n=3)$. Means with different superscripts in the same row indicate significant difference based on Duncan's multiple range test $(p<0.05)$. 

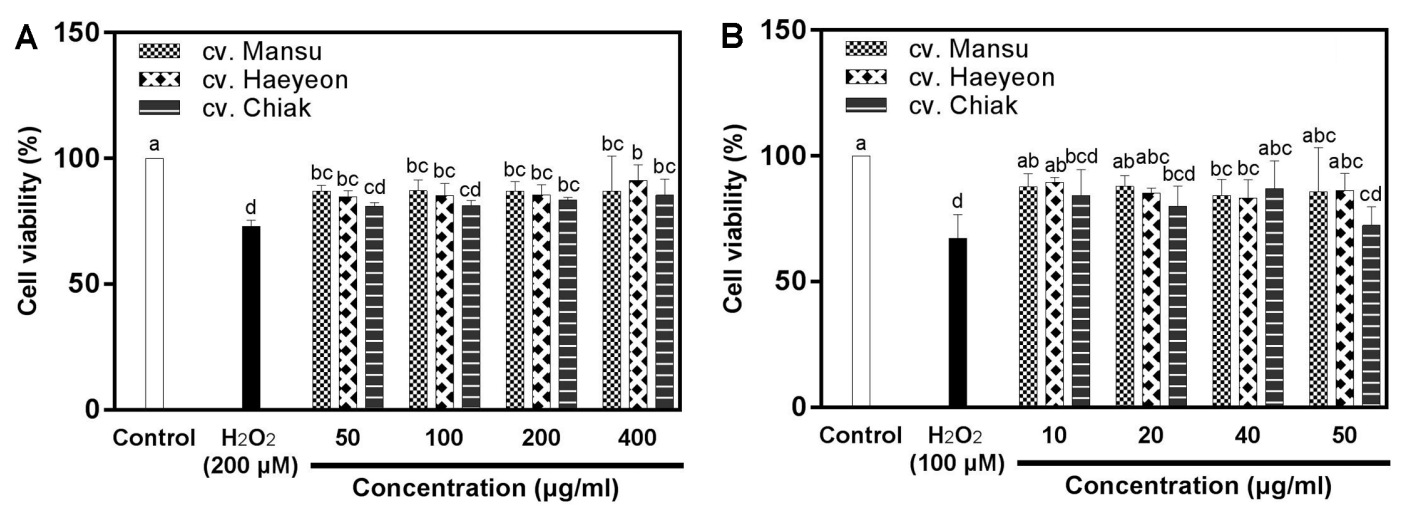

Fig. 1. Protective effects of three cultivars of hardy kiwifruit on neuronal PC-12 (A) and SH-SY5Y (B) cells against $\mathrm{H}_{2} \mathrm{O}_{2}$-induced oxidative stress measured using the MTT assay. The data are displayed as mean \pm standard deviation (bars) of three replicates. Different letters on the bars indicate significant difference determined by Duncan's multiple range test $(p<0.05)$.

\section{Inhibitory Effects of Hardy Kiwifruits on Intracellular Oxidative Stress}

Neurons are particularly susceptible to oxidative stress caused by ROS such as $\mathrm{H}_{2} \mathrm{O}_{2}$. Neurons are damaged and die after prolonged exposure to oxidative stress, which ultimately leads to reduced production of neurotransmitters such as AChE and can result in neurodegenerative diseases such as Alzheimer's disease. Therefore, natural product-based functional materials are needed to protect neurons from oxidative stress.

Pretreatment of PC-12 cells with $200 \mu \mathrm{M} \mathrm{H}_{2} \mathrm{O}_{2}$ showed $464.6 \%$ of intracellular oxidative stress (Fig. 2A). Pretreatments with extracts of cv. Mansu $(200$ and $400 \mu \mathrm{g} / \mathrm{ml})$ and $\mathrm{cv}$. Haeyeon $(400 \mu \mathrm{g} / \mathrm{ml})$ resulted in significantly $(p<0.05)$ reduced intracellular oxidative stress compared to that in PC- 12 cells induced with $\mathrm{H}_{2} \mathrm{O}_{2}$ (Fig. 2A). The intracellular oxidative stress of PC-12 cells treated with cv. Mansu extract of $400 \mu \mathrm{g} / \mathrm{ml}$ decreased from $464.6 \%$ to $194.6 \%$, which is a $58.1 \%$ decrease of the original oxidative stress level $(464.4 \%)$.

Intracellular oxidative stress of SH-SY5Y cells induced with $100 \mu \mathrm{M} \mathrm{H}_{2} \mathrm{O}_{2}$ was $188.5 \%$ (Fig. 2B). Pretreatment with hardy kiwifruit extracts except cv. Haeyeon $(10 \mu \mathrm{g} / \mathrm{ml})$ and cv. Chiak $(10$ and $20 \mu \mathrm{g} / \mathrm{ml})$ showed a significant $(p<0.05)$ decrease in intracellular oxidative stress compared to the SH-SY5Y cells induced with only $\mathrm{H}_{2} \mathrm{O}_{2}$ (Fig. 2B). SH-SY5Y cells treated with cv. Mansu, cv. Haeyeon, and cv. Chiak extracts at $50 \mu \mathrm{g} / \mathrm{ml}$ showed intracellular oxidative stresses of $121.7 \%, 118.9 \%$, and $113.6 \%$, respectively, which correspond to intracellular oxidative stress decreases of $35.4 \%, 36.9 \%$, and $39.7 \%$, respectively.

It was previously reported that hardy kiwifritus reduced the intracellular oxidative stress of PC-12 cells [5]. Phenolics have protective effects on neuronal cells against oxidative stress due to their antioxidative effects [20, 26]. Vitamin $C$ and phenolics such as (-)-epicatechin, isoquercitrin, hyperoside, procyanidin $B 2$, and rutin have been reported to protect PC-12 cells against oxidative stress [20,27-29]. Hence, the antioxidative phenolics and vitamin C identified in hardy kiwifruits, as listed in Table 2, may protect neuronal cells against oxidative stress (Figs. 1 and 2).

\section{Anti-Cholinesterase Effects of Hardy Kiwifruits}

AChE rapidly hydrolyzes the neurotransmitter acetylcholine into choline and acetate, terminating neurotransmission in cholinergic neurons [30]. BChE (pseudocholinesterase) also hydrolyzes acetylcholine,
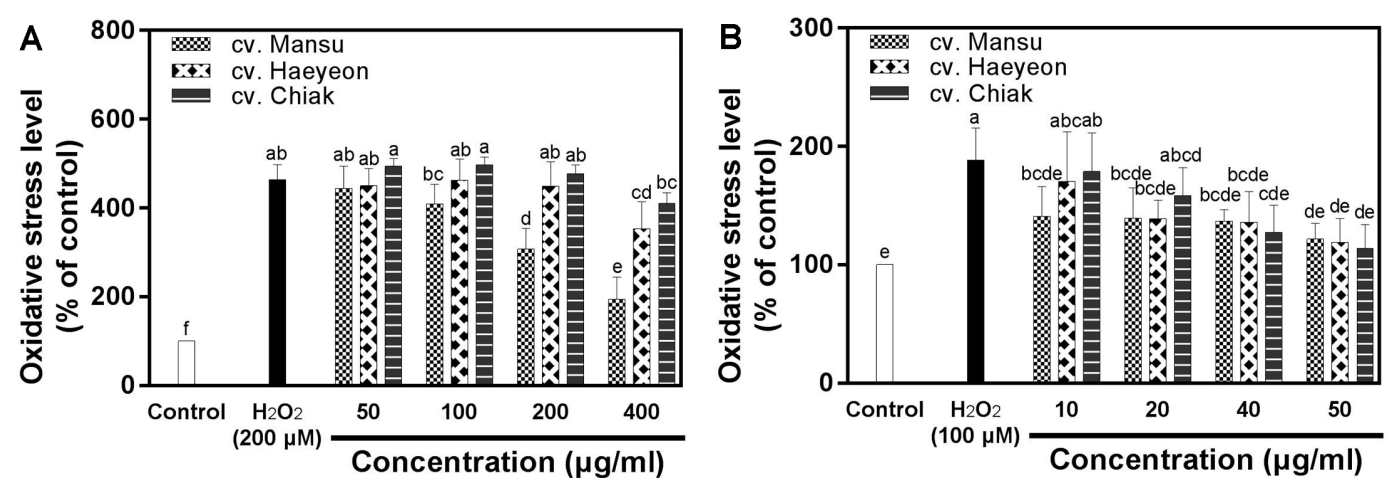

Fig. 2. Effects of three cultivars of hardy kiwifruit on intracellular oxidative stress in neuronal PC-12 (A) and SH-SY5Y (B) cells exposed to $\mathrm{H}_{2} \mathrm{O}_{2}$-induced oxidative stress measured using the DCFH-DA assay. The data are displayed as mean \pm standard deviation (bars) of three replicates. Different letters on the bars indicate significant difference determined by Duncan's multiple range test $(p<0.05)$. 

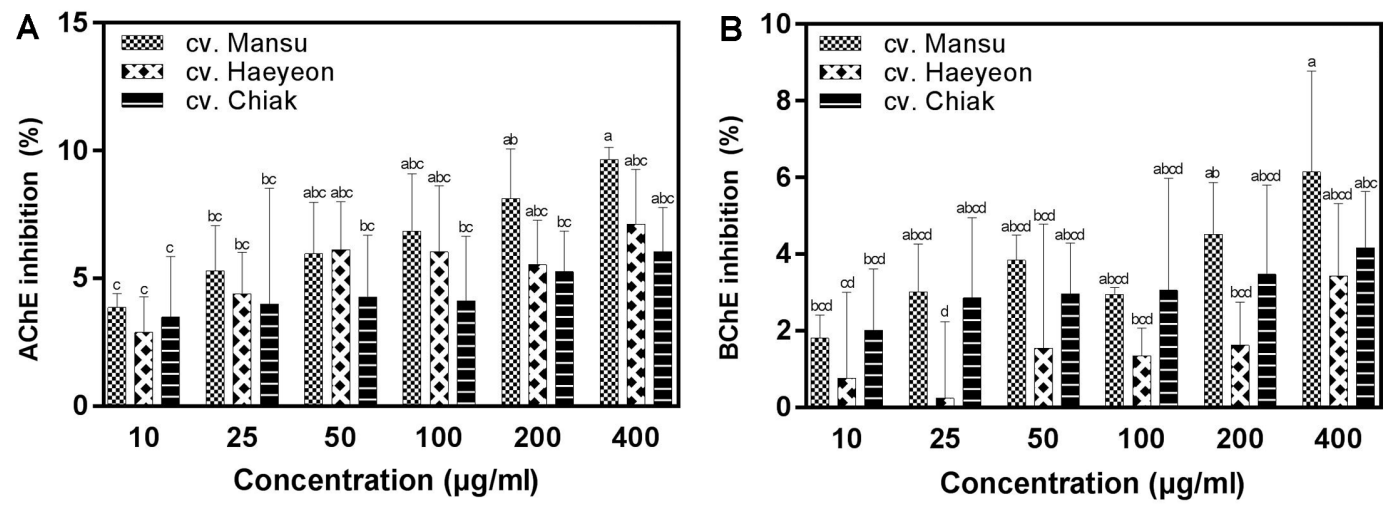

Fig. 3. Inhibitory effects of three cultivars of hardy kiwifruit on acetylcholinesterase (AChE; A) and butyrylcholinesterase (BChE; B) activity. The data are displayed as mean \pm standard deviation (bars) of three replicates. Different letters on the bars indicate significant difference determined by Duncan's multiple range test $(p<0.05)$.

acting as a co-regulator in acetylcholine neurotransmission [31]. Inhibition of AChE and BChE maintains neuronal acetylcholine level through inhibition of neurotransmitter degradation, which supports neurotransmission of cholinergic synapses.

As shown in Fig. 3, the extracts of the three cultivars of hardy kiwifruit inhibited two cholinesterases, AChE and BChE, suggesting that they may be a useful source of cholinesterase inhibitors. The extracts of cv. Mansu, cv. Haeyeon, and $\mathrm{cv}$. Chiak at concentration of $400 \mu \mathrm{g} / \mathrm{ml}$ produced moderate AChE inhibitory activities of approximately $9.7 \%, 7.1 \%$, and $6.0 \%$, respectively, whereas their BChE inhibitory activities were approximately $6.1 \%, 3.4 \%$, and $4.1 \%$ (Fig. 3). Cv. Mansu had higher inhibitory AChE and BChE activities than the other cultivars used in this study. Hardy kiwifruit extracts at the same concentration had higher inhibition of AChE than BChE. Total phenolic content was previously reported to be correlated with the inhibitory activities of AChE and BChE [32]. Phenolics including (-)-epicatechin, isoquercitrin, procyanidin $B 2$, and rutin have been reported to inhibit $\mathrm{AChE}$ and $\mathrm{BChE}[29,33]$. The anti-cholinesterase effects of hardy kiwifruits in this study indicate that AChE and $\mathrm{BChE}$ inhibition activities are due, at least in part, to phenolics.

In conclusion, hardy kiwifruits were confirmed to be rich in phenolics and to exhibit antioxidant capacity. Hardy kiwifruit extracts demonstrated neuroprotective effects by increasing the viability of neuronal cells and reducing intracellular oxidative stress. Hardy kiwifruit extracts showed inhibitory effects on AChE and BChE. Taken together, the results of this study suggest that hardy kiwifruits rich in antioxidant phenolics and vitamin C potentially possess neuroprotective effects. In the future, further study of the effects of hardy kiwifruits and their phenolics on anti-dementia in an in vivo animal model is warranted.

\section{Acknowledgments}

This research was supported by the Agricultural Biotechnology Development Program (Project No. 114076-3), Ministry of Agriculture, Food, and Rural Affairs, Republic of Korea.

\section{Conflict of Interests}

The authors have no financial conflicts of interest to declare.

\section{References}

1. Li H-Y, Yuan Q, Yang Y-L, Han Q-H, He J-L, Zhao L, et al. 2018. Phenolic profiles, antioxidant capacities, and inhibitory effects on digestive enzymes of different kiwifruits. Molecules 23: 2957.

2. Nishiyama I, Yamashita Y, Yamanaka M, Shimohashi A, Fukuda T, Oota T. 2004. Varietal difference in vitamin C content in the fruit of kiwifruit and other Actinidia species. J. Agric. Food Chem. 52: 5472-5475.

3. Latocha P, Jankowski P, Radzanowska J. 2011. Genotypic difference in postharvest characteristics of hardy kiwifruit (Actinidia arguta and its hybrids), as a new commercial crop Part I. Sensory profiling and physicochemical differences. Food Res. Int. 44: 1936-1945.

4. Wojdyło A, Nowicka P, Oszmiański J, Golis T. 2017. Phytochemical compounds and biological effects of Actinidia fruits. J. Funct. Foods 30: 194-202.

5. Lee I, Lee BH, Eom SH, Oh C-S, Kang H, Cho Y-S, et al. 2015. Antioxidant capacity and protective effects on neuronal PC-12 cells of domestic bred kiwifruit. Korean J. Hort. Sci. Technol. 33: 259-267.

6. Jung BJ, Cho HS, Park MY, Cho YS. 2016. 'Mansu', a hardy kiwifruit (Actinidia arguta Planch. et Miq.) cultivar with improved storage life. Korean J. Hort. Sci. Technol. 34: 755-760.

7. Méndez-Armenta M, Nava-Ruíz C, Juárez-Rebollar D, Rodríguez-Martínez E, Gómez PY. 2014. Oxidative stress associated with neuronal apoptosis in experimental models of epilepsy. Oxid. Med. Cell. Longev. 2014: 293689.

8. Ataie A, Shadifar M, Ataee R. 2016. Polyphenolic antioxidants and neuronal regeneration. Basic Clin. Neurosci. 7: 81-90.

9. An X, Lee SG, Kang H, Heo HJ, Cho Y-S, Kim D-O. 2016. Antioxidant and anti-inflammatory effects of various cultivars of kiwi berry (Actinidia arguta) on lipopolysaccharide-stimulated RAW 264.7 cells. J. Microbiol. Biotechnol. 26: 1367-1374.

10. Ha JS, Jin DE, Park SK, Park CH, Seung TW, Bae D-W, et al. 2015. Antiamnesic effect of Actinidia arguta extract intake in a mouse model of TMT-induced learning and memory dysfunction. Evid.-Based Complementary Altern. Med. 2015: 876484. 
11. Lim S, Han SH, Kim J, Lee HJ, Lee JG, Lee EJ. 2016. Inhibition of hardy kiwifruit (Actinidia aruguta) ripening by 1methylcyclopropene during cold storage and anticancer properties of the fruit extract. Food Chem. 190: 150-157.

12. Leontowicz M, Leontowicz H, Jesion I, Bielecki W, Najman K, Latocha P, et al. 2016. Actinidia arguta supplementation protects aorta and liver in rats with induced hypercholesterolemia. Nutr. Res. 36: 1231-1242.

13. Xue W-Z, Yang Q-Q, Chen Y, Zou R-X, Xing D, Xu Y, et al. 2017. Kiwifruit alleviates learning and memory deficits induced by $\mathrm{Pb}$ through antioxidation and inhibition of microglia activation in vitro and in vivo. Oxid. Med. Cell. Longev. 2017: 5645324.

14. Hwang J-S, Cho CH, Baik M-Y, Park S-K, Heo HJ, Cho Y-S, et al. 2017. Effects of freeze-drying on antioxidant and anticholinesterase activities in various cultivars of kiwifruit (Actinidia spp.). Food Sci. Biotechnol. 26: 221-228.

15. Lee BH, Nam TG, Cho CH, Cho Y-S, Kim D-O. 2018. Functional and sensory characteristics of kiwifruit jangachi cured with traditional Korean sauces, doenjang and kochujang. Korean J. Food Sci. Technol. 50: 238-243.

16. Kim Y-E, Cho C-H, Kang H, Heo HJ, Cho Y-S, Kim D-O. 2018. Kiwifruit of Actinidia eriantha cv. Bidan has in vitro antioxidative, anti-inflammatory and immunomodulatory effects on macrophages and splenocytes isolated from male BALB/c mice. Food Sci. Biotechnol. 27: 1503-1511.

17. Kim D-O, Jeong SW, Lee CY. 2003. Antioxidant capacity of phenolic phytochemicals from various cultivars of plums. Food Chem. 81: 321-326.

18. Benzie IFF, Strain JJ. 1996. The ferric reducing ability of plasma (FRAP) as a measure of "antioxidant power": the FRAP assay. Anal. Biochem. 239: 70-76.

19. Heo H-J, Cho H-Y, Hong B, Kim H-K, Kim E-K, Kim B-G, et al. 2001. Protective effect of 4',5-dihydroxy-3',6,7-trimethoxyflavone from Artemisia asiatica against A $\beta$-induced oxidative stress in PC12 cells. Amyloid-J. Protein Fold. Disord. 8: 194-201.

20. Kim J-W, Im S, Jeong H-R, Jung YS, Lee I, Kim KJ, et al. 2018. Neuroprotective effects of Korean red pine (Pinus densiflora) bark extract and its phenolics. J. Microbiol. Biotechnol. 28: 679-687.

21. Ellman GL, Courtney KD, Andres V, Jr., Featherstone RM. 1961. A new and rapid colorimetric determination of acetylcholinesterase activity. Biochem. Pharmacol. 7: 88-95.

22. Latocha P, Wołosiak R, Worobiej E, Krupa T. 2013. Clonal differences in antioxidant activity and bioactive constituents of hardy kiwifruit (Actinidia arguta) and its year-to-year variability. J. Sci. Food. Agric. 93: 1412-1419.

23. Baranowska-Wójcik E, Szwajgier D. 2019. Characteristics and pro-health properties of mini kiwi (Actinidia arguta). Hort. Environ. Biotechnol. 60: 217-225.

24. Kim D-O, Lee CY. 2004. Comprehensive study of vitamin C equivalent antioxidant capacity (VCEAC) of various polyphenolics in scavenging a free radical and its structural relationship. Crit. Rev. Food Sci. Nutr. 44: 253-273.

25. Kim JG, Beppu K, Kataoka I. 2009. Varietal differences in phenolic content and astringency in skin and flesh of hardy kiwifruit resources in Japan. Sci. Hortic. 120: 551-554.

26. Jeong D-W, Cho CH, Lee JS, Lee SH, Kim T, Kim D-O. 2018. Deastringent peel extracts of persimmon (Diospyros kaki Thunb. cv. Cheongdo-Bansi) protect neuronal PC-12 and SH-SY5Y cells against oxidative stress. J. Microbiol. Biotechnol. 28: $1094-1104$.

27. Liu Z, Tao X, Zhang C, Lu Y, Wei D. 2005. Protective effects of hyperoside (quercetin-3-O-galactoside) to PC12 cells against cytotoxicity induced by hydrogen peroxide and tert-butyl hydroperoxide. Biomed. Pharmacother. 59: 481-490.

28. Luo L, Bai R, Zhao Y, Li J, Wei Z, Wang F, et al. 2018. Protective effect of grape seed procyanidins against $\mathrm{H}_{2} \mathrm{O}_{2}$-induced oxidative stress in PC-12 neuroblastoma cells: structure-activity relationships. J. Food Sci. 83: 2622-2628.

29. Choi J, An X, Lee BH, Lee JS, Heo HJ, Kim T, et al. 2015. Protective effects of bioactive phenolics from jujube (Ziziphus jujuba) seeds against $\mathrm{H}_{2} \mathrm{O}_{2}$-induced oxidative stress in neuronal PC-12 cells. Food Sci. Biotechnol. 24: 2219-2227.

30. Čolović MB, Krstić DZ, Lazarević-Pašti TD, Bondžić AM, Vasić VM. 2013. Acetylcholinesterase inhibitors: pharmacology and toxicology. Curr. Neuropharmacol. 11: 315-335.

31. Darvesh S, Hopkins DA, Geula C. 2003. Neurobiology of butyrylcholinesterase. Nat. Rev. Neurosci. 4: 131-138.

32. Wojdyło A, Nowicka P. 2019. Anticholinergic effects of Actinidia arguta fruits and their polyphenol content determined by liquid chromatography-photodiode array detector-quadrupole/time of flight-mass spectrometry (LC-MS-PDA-Q/TOF). Food Chem. 271: 216-223.

33. Szwajgier D. 2013. Anticholinesterase activities of selected polyphenols - a short report. Pol. J. Food Nutr. Sci. 64: 59-64. 